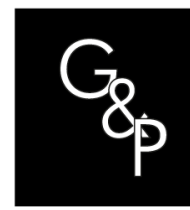

\title{
Case study for the development of an analysis structure for the collaborative environment on project companies
}

\author{
Estudo de caso para o desenvolvimento de uma estrutura de análise \\ para o ambiente colaborativo em empresas de projeto \\ Patrícia da Silva Fiuza Pina ${ }^{1}$ (D), Raquel Naves Blumenschein ${ }^{1}$ (D) \\ ${ }^{1}$ Universidade de Brasília - UnB, Faculdade de Arquitetura e Urbanismo - FAU, Programa de Pós-graduação - PPG, \\ Laboratório do Ambiente Construído, Inclusão e Sustentabilidade - LACIS, Brasília, DF, Brasil. E-mail: \\ patricia.fiuza@hotmail.com; raquelblum@terra.com.br
}

How to cite: Pina, P. S. F., \& Blumenschein, R. N. (2020). Case study for the development of an analysis structure for the collaborative environment on project companies. Gestão \& Produção, 27(4), e4764. https://doi.org/10.1590/0104-530X4764-20

\begin{abstract}
This research presents an analysis of the paradigm that involves the collaborative management in technological environments of architectural and urban planning companies, in the Brazilian scenario. It associates Administration, Architecture, Engineering and Construction (AEC), and Behavioural Analysis perspectives. It is based on a review about the influencing factors inserted in BIM domain as learning process boosters, associating concepts of collaborative networks, project management, dynamic capabilities and meta-contingencies to discuss a class of problems arising from the lack of knowledge absorption, which was systematized in the study of management bottlenecks. The methodological approach, based on Design Science Research, synthesizes procedures compatible with the general typology of an artefact -a support tool - associated to a functional analysis. The obtained results highlight seven variables that represent categories of analysis of the collaborative environment: activities, self-assessment, BIM, decision-making, information, resources, and values. The main contribution of this research was to develop a methodological way to complement a partial diagnosis of project process management. It is the first step to develop an analysis structure that represents the dynamics of a collaborative network and not just isolated variables.
\end{abstract}

Keywords: BIM; Collaborative environment; Knowledge; Architectural companies; Management bottlenecks.

Resumo: Esta pesquisa apresenta uma análise do paradigma que envolve a gestão colaborativa em ambientes tecnológicos de empresas de projeto de arquitetura e urbanismo, no cenário nacional, associando as perspectivas da Administração, da Arquitetura, Engenharia e Construção (AEC) e da Análise do Comportamento. Parte-se de uma revisão sobre os fatores de influência inseridos no domínio BIM como impulsionadores de processos de aprendizagem, associando conceitos de redes de colaboração, de gestão do projeto, de capacidades dinâmicas e das metacontingências, para discutir uma classe de problemas oriunda da falta de absorção de conhecimento, que foi sistematizada no estudo dos gargalos da gestão. A abordagem metodológica, fundamentada na Design Science Research, sintetiza procedimentos compativeis com a tipologia geral de um artefato, uma ferramenta de apoio associada a uma análise funcional. Os resultados obtidos

Received Apr. 7, 2018 - Accepted Aug 22, 2018

Financial support: FAP-DF.

(c) (i) This is an Open Access article distributed under the terms of the Creative Commons Attribution License, which permits unrestricted use, distribution, and reproduction in any medium, provided the original work is properly cited. 
destacam sete variáveis que representam categorias de análise do ambiente colaborativo: atividades, autoavaliação, BIM, decisões, informação, recursos e valores. A principal contribuição dessa pesquisa foi desenvolver um caminho metodológico para complementar um diagnóstico parcial de gerenciamento do processo do projeto como primeiro passo para desenvolver uma estrutura de análise que represente a dinâmica de uma rede de colaboração e não, apenas, variáveis isoladas.

Palavras-chave: BIM; Ambiente colaborativo; Conhecimento; Empresas de projeto; Gargalos da gestão.

\section{Introduction}

In Architecture, Engineering and Construction (AEC) sector, collaboration and collaborative work supported by computers are central themes in the discussion about the management of project companies, whose productive cycle requires extensive reformulation in the national (Brazilian) scenario. This trend presents an opportunity to achieve competitive advantages in the sector, advancing the quality of project's productive process and implementation and strengthening of collaborative networks.

However, in the national scenario, project companies show a slow and fragmented process of adoption of technologies (Manzione, 2013). It reflects a gap in learning processes - triggering elements of technological and collaborative environments that arise and grow over time, but are reinforced by awareness of interactions between individuals or network "nodes" (Cândido \& Abreu, 2000; Blumenschein, 2004).

In this context, it is common to attempt to develop the project productive processes dissociated from its technological tools, whether BIM (Building Information Modelling) focused on IPD (Integrated Project Delivery) process, or IDDS (Integrated Design and Delivery Solutions). It reflects the barriers to management systems and the difficulty in advancing the current technological paradigm (Brandon, 2009; Owen et al., 2010; Manzione, 2013).

It should be noted that these barriers are connected to a class of problems arising from the lack of knowledge absorption on Brazilian project companies. This issue is systematized in this research by broaden the study of project process bottlenecks (Fiuza, 2015). This configuration, according to Lacerda et al. (2013, p. 744), starts from a real problem in a singular socio-technological context, yet it can "[...] enable the generalization and the knowledge advancement in this area".

It is also argued that there is a need of research in the field of management, in the organizational perspective (Ford et al., 2003; Lacerda et al., 2013), aiming at the processes improvement. Lacerda et al. (2013) observe that the construction of artefacts for problem solving is an appropriate contribution in the area of technology in a variety of management fields.

On the other hand, this scenario has potential reinforcers, as Manual BIM de Santa Catarina, a core-document aligned with various standards, among them ISO 16739:2013, which provides procedures for adoption of building information modelling, aiming at the parametrization of future auction notices for contracting projects; the dynamic of project teams formation; and the advantages linked to the new construction processes inserted in the paradigm pointed out by Kolarevic (2005) in Architecture in the Digital Age - Design and Manufacturing.

Considering that BIM is a disruptive technology and an agent of change in business processes, there is an wide adoption of the tool in AEC industry (Eastman et al., 2014; Fenby-Taylor et al. 2016; Harun et al., 2016; NBS, 2017; Wu et al., 2018). The definition of BIM encompasses the modelling environment and the model, characterized as a "[...] process based in shared, integrated and interoperable digital-models" (Manzione, 2013, p. 36), whose products, the models, are called Building Information Models. The critical 
analysis of the nine guides published from 2006 to 2010 for the implementation of BIM (Building Information Modeling), conducted by Manzione (2013), has been updated in this search until 2018, corroborating the premise that there is a gap in the proposition of structures of management in BIM.

In the meantime, two manuals have been updated: Building Information Modeling Roadmap (US Army Corps of Engineers - USACE, 2012); and BIM Project Execution Planning Guide and Templates (Penn State BIM, 2012). In addition, five other books have been added to the list: Development of IFCs for the Structural Domain, Strategic Work Plan (Applied Technology Council, Charles Pankow Foundation, and technical team, 2008); AIA Integrated Project Delivery (the American Institute of Architects - AIA, 2007); The Guia AsBEA boas práticas em BIM [AsBEA good practices in BIM] (GTBIM, 2015); Indiana University's BIM Proficiency Guide (Indiana University, 2015); and Manual BIM de Santa Catarina (Santa Catarina's Government, Secretariat of Planning, GTBIM and colaborators, 2014).

In this context, the main objective of this research is to identify variables that are compatible with the class of problems systematized by the study of management bottlenecks - variables that contribute to the development of a future analysis framework compatible with collaborative technology management in project companies, in the perspective of Administration, AEC and Behaviour Analysis.

In order to fulfil this objective, the methodological approach is grounded on the context of Design Science Research, according to Lacerda et al. (2013), synthesizing procedures compatible with the typology of the general artifact (March \& Smith, 1995; Simon, 1996; Lacerda et al., 2013). Presenting a single case study in this research, "company A", converges to the thought of Flick (2009) about the fact that the beginning is always from a single case before comparative analysis. Thus, we tried to identify the interrelations between the variables found in order to observe "[...] patterns in data and to develop conceptual categories that allow to illustrate, confirm or refuse the theoretical assumptions" (Godoy et al., 2012, p. 124). In this way, case studies can be motivated by conceptual studies, or propose the broadening of certain concepts, but, above all, they are compatible with Design Science Research by allowing the artifacts formalization, in a given context, aiming at replications in other organizations (Van Aken, 2004).

This article is structured as follows: initially, we present a review of the influencing factors of technological-collaborative environments in AEC, inserted in BIM domain. Then, there is a contextualization of cooperation and collaboration concepts as drivers of the learning processes inherent to the class of problems that will be defined throughout the study of management bottlenecks. Then, we present the methodological procedures, followed by the application of a support tool called Ferramenta de Apoio ao Processo do Projeto - FAPP [Support Tool for the Project Process], and associated to functional analysis. As a result, it can identify the variables from analysis components compatible with this class of problems. Finally, the main contributions of the research are reported, exposing their limitations and final considerations.

\section{Theoretical framework}

In order to develop collaborative networks and strengthen the integration among agents involved in a project process in BIM domain it is necessary to deal with barriers related to project process management, technological systems and processes deployment. Such barriers may have an impact in the perception of the link between project process, company's competitive strategy and added value of the project (e.g. 
American Institute of Architects, AIA, 2007; Brandon, 2009; Owen et al., 2010; Manzione, 2013; Eastman et al., 2014).

As for the deployment of processes, it is necessary to highlight that the conventional way of production of projects in Brazilian companies happens by means of CAD processes (Computer Aided Design), collaborative on certain levels, but not integrated. Yarmohammadi \& CastroLacouture (2018) explain that this type of process presents failures in the transmission of project information, which affect the monitoring and present unstructured data (that do not interact with the model generated, nor can be automatically read).

However, the understanding of the current paradigm of project production process is not supported only in CAD logic. It involves cultural, socioeconomic, and technological issues molded from variations in knowledge absorption, in the development of technical capabilities and standardization of the various sectors of construction industry, under different contexts (Gu \& London, 2010; Wong et al., 2010; Fellows \& Liu, 2013; Manzione, 2013, Eastman et al., 2014; Wu et al., 2018; Garcia et al.; 2018).

From studies by Gu \& London (2010), Eastman et al. (2014), Garcia et al. (2018), Charef et al. (2018) and Wu et al. (2018), we list some factors that cause BIM underutilisation and hamper the progress in this paradigm: the lack of governmental support for acceleration of BIM implementation; lack of alignment between workers and academics for dissemination of the tool; perception that BIM is only done to produce fancy threedimensional models or for projects of complex functions; unawareness of the coordination and collaboration between different disciplines; the issue of deal with the initial costs of BIM implementation (licenses, training and/or hiring experts); implementation of a cycle of adoption and diffusion of technology without incorporating knowledge absorption as the initial step.

In this context, the process of absorbing and sharing knowledge - required to drive technologically the national project companies - is still heterogeneous, fragmented and perceived as dissociated. The relationship between knowledge absorption and sharing, observed by Ping Tserng \& Lin (2004) and Tomomitsu et al. (2018) in many areas, and Wu et al. (2018) in the segment of AEC, is present in advanced economies and represent critical factors for success of an organization. Wu et al. (2018) specify also that the rapid growth in BIM adoption and implementation in the United States, England and China has resulted in a sustained boost in global construction industry on the segments of AEC.

Gusberti et al. (2015) point out the knowledge absorption, in the approach "VisionBased Capabilities", as a driving force to unlock existing capacities and create new abilities (control of BIM tool), configuring new products (in this case, projects). Such dynamic may also influence patterns of business management (management in BIM) (Helfat et al., 2007; Savory, 2006; Gusberti et al., 2015).

The studies of Wheelwright \& Clark (2011) demonstrate that the development of products includes activities of combination, establishment of connections and refinement. Understanding projects as results from technological solutions should, comparably, lead to connect elements to concepts or principles. In this case, it is essential that the innovation is linked to sustainability. These connections allow shaping an architecture inserted in BIM domain in order to fulfil a function that responds to a social demand. For this reason, the project production process can also be described as a "[...] combinatorial ability" in which occurs the connection between existing and externally acquired knowledge (Gusberti et al., 2015, p. 924).

In this perspective, the absorption of BIM learning presents a logic of connectivity similar to that presented by Kogut \& Zander (1992) and Arthur (2010), in which the activities of aggregate value to the project company occur during the development of innovative and sustainable technological solutions, following a chain of problem-solving, 
decisions and balance of constraints that will enable the construction of the project, incorporating the learned processes as part of the company's dynamic.

Keeping in mind the problematic exposed, the central questions of this research are: (i) how to define a class of problems that is compatible with the current technological paradigm and (ii) which variables - compatible with this class of problems - could be identified to parameterize a analysis structure for technologicalcollaborative environment of project companies.

In order to answer the first question, it was necessary to investigate the drivers and constraints of collaborative-technological environments in AEC, inserted in BIM domain, organizing and expanding them systematically in a study on the class of problems inherent to knowledge absorption: the management bottlenecks.

In this context, the phenomenon of cooperation and collaboration has been investigated, but in a fragmented way (Franco, 2007; Parkhe, 1991, Oliver \& Ebers, 1998), which may imply a gap in learning processes on design process management, as a driver of the networks that emerge and grow over time, but are strengthened by the interactions between individuals (Cândido \& Abreu, 2000; Blumenschein, 2004).

Tomomitsu et al. (2018), supported by Kodama (2005), highlight the strategic communities as triggers for knowledge absorption and dissemination, crediting it to the levels of immersion in process of collaboration and company values resonance. Similarly, this dynamic happens in BIM domain in design companies. It may produce innovations, effect predicted by Kodama (2005) in organizations that are able to form networks.

Various approaches of empirical studies of companies' networks point out paramount factors for cooperation and collaboration process as business strategy, applicable in this research, according to Table 1 :

Table 1. Aspects of cooperation and collaboration process applicable to project companies.

\begin{tabular}{|c|c|}
\hline $\begin{array}{l}\text { Important factors in the } \\
\text { cooperation and collaboration } \\
\text { between companies. }\end{array}$ & $\begin{array}{l}\text { Important factors for the collaborative network in } \\
\text { design companies. }\end{array}$ \\
\hline $\begin{array}{l}\text { Compatibility of objectives (Bronder } \\
\text { \& Pritzl, 1992; Franco, 2007) }\end{array}$ & $\begin{array}{l}\text { Alignment of the objectives of the company and the } \\
\text { projects/ portfolio of projects. }\end{array}$ \\
\hline Partners' needs (Baird et al., 2007) & $\begin{array}{l}\text { Expectations and demands are converted into project } \\
\text { requirements; attributes are translated into performance } \\
\text { requirements. }\end{array}$ \\
\hline $\begin{array}{c}\text { Mutual trust and commitment } \\
\text { (Bhattacharya, Devinney \& Pillutla, } \\
\text { 1998) }\end{array}$ & $\begin{array}{c}\text { Strengthening the collaborative network; Collaborative } \\
\text { Approach in design process; Formal and informal } \\
\text { communication channels. }\end{array}$ \\
\hline $\begin{array}{l}\text { Balance of power and control (Inkpen } \\
\qquad \& \text { Beamish, 1997) }\end{array}$ & $\begin{array}{l}\text { Make it clear which are the systems of authority and } \\
\text { influence; The alignment of the objectives of the company } \\
\text { and of the project; Control the arbitrary nature of decisions; } \\
\text { Aspects of management, operation and feedback. }\end{array}$ \\
\hline $\begin{array}{l}\text { Cultural similarities (Bronder \& Pritzl, } \\
\text { 1992; Hennart \& Zeng, 2002) }\end{array}$ & $\begin{array}{l}\text { More flexible companies; Agents acquire the knowledge, } \\
\text { skills, techniques, and identification to act as a team. }\end{array}$ \\
\hline $\begin{array}{l}\text { Balance of forces between the } \\
\text { partners (Bleeke \& Ernst, 1991; } \\
\text { Osland \& Cavusgil, 1996) }\end{array}$ & $\begin{array}{l}\text { Analysis of needs of external and internal agents; Individual } \\
\text { and collective consciousness of the influences and impacts }\end{array}$ \\
\hline $\begin{array}{l}\text { Governmental support (Baird et al., } \\
\text { 2007) }\end{array}$ & $\begin{array}{l}\text { Legal requirements, processes for review and approval by } \\
\text { the public power; Clear identification and update of } \\
\text { technical standards; Compliance with Norma de } \\
\text { Desempenho [performance standards]; Support for } \\
\text { implementation of BIM platform; SNA. }\end{array}$ \\
\hline
\end{tabular}


From Table 1, we discuss potential factors for the design companies to achieve competitive advantages - in addition to adoption of technological tools, an investment that may be lost or under-utilized if these factors are not considered, what Eastman et al. (2014) called changes on the current work paradigm.

This advancement towards BIM domain involves the reduction of interfaces, processes, protocols and communication (Eastman et al., 2014; Manzione, 2013). Therefore, it is included in the relation between capacity and ability for technological development. Such relation can be referenced by the perspective of SNA - Sistema Nacional de Aprendizado [National Learning System], according to Viotti (1997), with emphasis on learning, allowing for technological change over time, and later, by the continuous introduction of incremental change.

In this sense, to implement and develop collaborative networks may be a means to have access to know-how that cannot be produced internally - only in more complex communication networks, which sustain the conditions for innovation, notably an incentive for learning processes, which, according to Powell (1990), sustain network ecologies.

Considering it, the identication of variables from the relationships between collaborative environment bottlenecks will be useful, as they represent part of the existing dynamic in collaborative networks with a focus on knowledge absorption, allowing understanding how learning is processed and sustained.

Thus, we started from the study of design process bottlenecks, motivated by the investigation of the paradigm of learning process in project companies, to enable the construction of a quality assessment tool called Ferramenta de Apoio ao Processo do Projeto - FAPP [FAPP Design Process Support Tool] (Fiuza, 2015). This study lists the common factors of the design process productive cycle and its more representative faults. They are backed by themes such as design process cycle, quality, rationalization applied to operational and administrative field, and project management (e.g. Schon, 1984; Beer et al., 1999; Franco \& Agopyan, 1994; Melhado, 1994; Simon, 1997; Austin et al., 2002; Blumenschein, 2004; Boud, Cressey \& Docherty, 2006; AGESC, 2012; Manzione, 2013; Oliveira, 2013).

Broadening the study, the concept of "management bottlenecks" will elucidate technological and non-technological weaknesses that prevent the absorption of knowledge necessary to move forward in BIM domain paradigm. These bottlenecks are barriers arising from the lack of training of agents, extrapolation of schedule, failures in formal and informal communication, excessive reliance on managers expertise (without the necessary technical support) and fragile articulation of the project team (who does not know how to behave in network).

These weaknesses may occasionally become potentials, and there is likelihood that the overcome bottlenecks influence the knowledge absorption and strengthening of skills, such as collaboration, disseminating information to future projects and feeding learning processes and the quest for knowledge.

Figure 1 represents the broadening of this study to the field of management, noting that each company has a technological and collaborative reach that varies in intensity and also not necessarily the bottlenecks are all solved at the same time.

Furthermore, each bottleneck will be presented conceptually, in the perspective of Administration, AEC and CA, applying the concepts of collaborative networks (Jarillo, 1988; Powell, 1990; Saxton, 1997; Cândido \& Abreu, 2000; Loss, 2007), project management (Eastman et al., 2014; Manzione, 2013) and meta-contingencies (Malott, 2003; Malott \& Glenn, 2006; Glenn et al., 2016).

Thus, the first bottleneck is "technical training in specific fields", a concept which covers the concept of technical training as the required behaviour, knowledge, and performance to perform certain functions, proceeding to investigate such relations in BIM domain. 


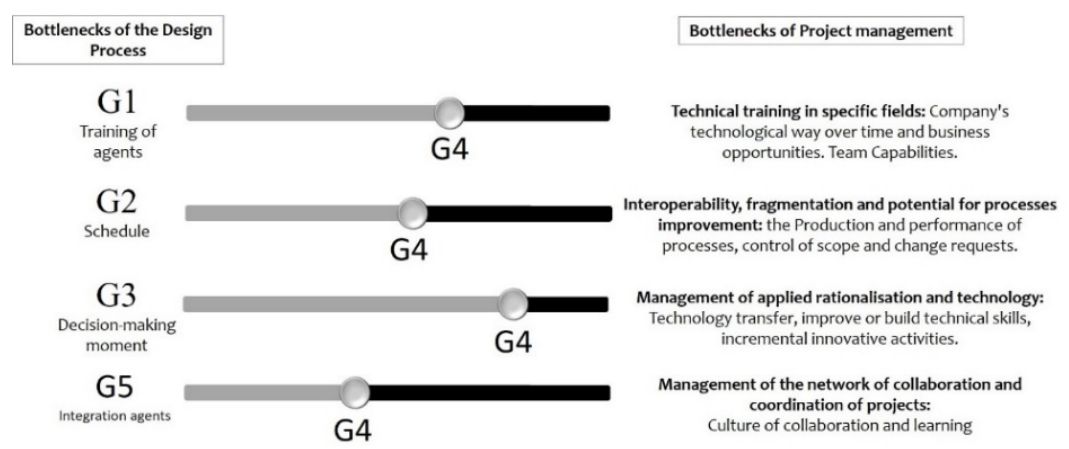

Figure 1. Expanding the study of bottlenecks. Source: Adapted from Fiuza (2015). Note: The broadening of this study changed the comprehension of bottleneck G4 (information flow), formerly analysed separately for project production process. Now, G4 is the structuring element of project management, whose focus is information management (domain of the process, the project, and alignment with market for growth and technological solutions).

On team scale, these functions inserted in BIM domain have a relationship with the transfer of structured data of the project (Eastman et al., 2014; Yarmohammadi \& CastroLacouture, 2018) and, specifically, with the ability to connect information across BIM dimensions and disciplines, analysis of scenarios, extraction of quantitatives, building modelling and planning (Charef et al., 2018; Garcia et al., 2018).

In the relationship of the team with the manager, such functions are influenced by the existing leadership, in which the manager responds verbally (formal and/or informal communication) to project team. The variables that control their behaviour are the result of a diagnosed problem-situation (the project that needs to meet a social demand). The manager verbal response represents a stimulus that can be a positive reinforcer. This functional relationship of variables characterizes a simplified social interaction (social communication) by means of an authoritative behaviour (Skinner, 1957) with a specific reinforcer.

On the project company level, these functions are particularly related to management processes of communication, of risks, and of analysis of internal and external environments, a context close to the one investigated by Houmanfar \& Mattaini (2016). They analyse the investigation of a problem-situation by correlating it with the interactions between agents, recognising that coherent verbal networks can influence the decisions of other agents.

The second bottleneck is "interoperability, fragmentation and potential for processes improvement", which represents the diagnosis of fragmentation levels and the potential for processes improvement, whose focus is on the production and performance of these processes, control of scope and requests for changes (Prins \& Owen, 2010; Eastman et al., 2014; Garcia et al., 2018; Charef et al., 2018).

This definition encompasses the premise that guides the bottleneck "schedule", in which, "[...] the components, activities, services or deliveries [...] must be preceded by planning, based on the project nature and within the convenient limits" (Fiuza, 2015, p. 50). In this sense, Manzione (2013) and Eastman et al. (2014) show that collaborative platforms focused on BIM can reduce communication barriers, bringing together the actual and the desirable schedule, rethinking the way projects are produced, their relationships and responsibilities.

The third bottleneck presented will be "management of applied rationalisation and technology", a concept that covers the impacts of decisions on projects, the treatment of specific information and the inherent potential for change in decision-making process. In this case, the focus is on the moments of absorption and selection of R\&D technologies, 
training, design guidelines and BIM deployment (AIA, 2007; Eastman et al., 2014; Garcia et al., 2018).

According to Parolia et al. (2007), in organizational environments the horizontal coordination provides greater autonomy to decision-making processes and presents clearly roles and responsibilities. From behavioural perspective, there is a positive perception of the project team, with a high degree of knowledge transfer, which is compatible with BIM domain. For Gusberti et al. (2015, p. 923), this horizontal alignment can be better leveraged if there is a management of capacities, which allows the "[...] integration, integrated management, and control of abilities according lines of actions", making it easier to align design solutions with the knowledge acquired by the designers, to deliver what the customer needs.

Vertical coordination, from the perspective of the authors, can be analysed in the relation of the manager with the team. In addition, for Skinner (1957), this is a contingency that will be shaped by former and consequent events, and with their intrinsic reinforcers that will select patterns of action. In this case, the reinforcements may be arbitrary, programmed as bonus or verbal recognition, and also intrinsic reinforcements as success in a completed task and recognition by peers. For Andery (2010), such schedules of contingencies have the greatest likelihood of satisfaction, favoring the correspondence between complexity, clarity, consistency, and the cost of following the rules.

The fourth bottleneck presented, "management of the collaborative network and coordination of projects", begins with the premise of individual and collective perception of the agents involved around common grounds that generate integration (Fiuza, 2015), highlighting the factors that influence the collaboration of agents to allow changes and organizational learning (Eastman et al., 2014; Gusberti et al., 2015; Tomomitsu et al., 2018).

In behavioural perspective, collaborative networks are embedded in the approach of Glenn et al. (2016, p. 13) that treat meta-contingencies as the "[...] relation of contingency between: (1) recurrences of Interlaced Behavioural Contingencies (CCEs) having an aggregate product (AP), and (2) environmental selection of events or conditions". Therefore, the relationships of contingency between CCEs/PA and the pickingenvironment are the meta-contingencies (e.g. Glenn et al., 2016; Malott, 2003; Malott \& Glenn, 2006). In this condition, the actors involved behave in the same technologicalcollaborative environment, with or without geographical proximity, influencing each other in an interlacing of functional relying relationships, whose practices contribute to the company survival and achievement of competitive advantages.

In this environment, the agents' interactions represent these relationships, and their behaviours are the variables that determine them in function of the projects' deliveries. The final result is the aggregate product (PA), a project that can be empirically observed, analysed, and evaluated. According to Glenn et al. (2016), it is assumed that there is the possibility to start new cycles of projects if the PA generated by the competitive advantage is maintained by cultural practices that strengthen the collaborative network.

Therefore, meta-contingencies describe functional relationships in a level distinct from the individual level, by keeping in mind the relationships between cultural practices and their products aggregated into a project company. In this case, the cultural practices of the design company are influenced by its environmental factors (PMI, 2013). For Tomomitsu et al. (2018), as certain activities and practices of project management can foster organizational learning, as the environment and culture of the company can generate a combination of critical success factors for the diffusion of knowledge.

An analysis of the existing natural contingencies of reinforcement in this scenario is an interesting exercise and, in this case - although restricted to the organizational environment - it is valid and reflects the power relations observed by Houmanfar \& 
Mattaini (2016) and Holland (2016), when quoting the direct control and the society reinforcement systems.

In this way, the direct control is exercised by the strategic level of project companies, technical standards, Brazilian Norma de Desempenho [performance standards] environmental regulations, certification protocols and guidelines, influence arising from clients and implemented in project requirements, demands of society, economic conditions, cultural profile of the construction industry production, resources available on the market that influence technological solutions adopted, impacts of project on waste management, buildings sustainability and durability.

In relation to company staff, there is also confrontation with reinforcements based on acquisition of profit, privilege and personal status, encouraging competition instead of collaboration, and information secrecy instead of sharing.

Facing the strengthening of the collaborative network as a pressing challenge, the challenge of Holland (2016) is applicable, questioning how to operate a change in the management of an environment and with behaviour modification, "[...] so that the work can be potentially useful in the transformation of man toward a new system of revolutionary values?" (Holland, 2016, p. 115). For the national design companies, this "revolutionary" value could be included in the development of collaborative networks, from the solving of bottlenecks that prevent knowledge absorption.

\section{Methodological procedures}

This research is inserted in the perspective of Design Science Research, in which, according to Lacerda et al. (2013), the analysed object's nature is on the organizational environment of the national project companies. This artificial environment, according to Simon (1996), investigated from the academic point of view, represents the interface between an internal environment (project company), a collaborative platform - BIM domain - and an external environment (market).

The management bottlenecks presented in the Theoretical framework shape what Lacerda et al. (2013) call the "vocabulary of a domain" and that, in the perspective of March \& Smith (1995), describe a class of problems within this domain (BIM) in design companies: the knowledge absorption. This study is part of the construction of an artifact - the FAPP tool - completed and applied for the first time in 2015 , in a sample of three small design companies and two micro design-companies, located in Distrito Federal.

The research has combined primary data sources that relate to the application of FAPP by means of questionnaires and semi-structured interviews that, according Triviños (1987), are tools that start from basic questions, but offer a variety of questions to the respondent. The sources of secondary data, already collected and available (Yin, 2001), are related to the literature review conducted and the relations and interpretations of data in functional analysis.

Item 4.1 - Application, presents the application of FAPP in company A, in 2017, resulting in a diagnostic representative of the bottlenecks in technical training, a moment of decision-making and integration between agents. Then, item 4.2 - functional Analysis presents the investigation on certain organizational practices in the perspective of Behavioral Analysis. Finally, in item 4.3 - Variables and guidelines, we present the variables obtained for the construction of a future Analysis Framework, using as methodological reference the research made by Loss (2007).

About the participant, a small-sized project-company, according to the legal definition brought by "[...] art. $3^{\circ}$, incisos I e II, da Lei Complementar $n^{\circ} 123$, de 14 de dezembro de 2006" (Brasil, 2006), with operation field on architecture and urbanism. Located in Distrito Federal, with national 
coverage, it had already applied FAPP support tool, therefore, the selection criterion was the interest on the results of the expanded tool. The unit of analysis is the set of behavioural and operational practices of company A, acting in a collaborative network. The unit of observation is composed by project team, manager and company shareholders, as informants of the company's practices.

\subsection{Instrument}

FAPP tool has been used, parameterized by the study of design process bottlenecks (Fiuza, 2015). Due to the scope of this article, we present the final interface of the tool (Figure 2) and list, with no demonstration, its construction steps: identification of the application boundaries (physical delivery of the project); identification of critical points in project process and its bottlenecks; characterization of checkers (tangible components for investigation, such as documents, reports and data from deliveries of each project phase); list of requirements (ABNT, 2005); list of criteria (quantitative profile); application of global scales of attainment/ usage and degrees of importance (adapted from Beber, 2008); development of diagnostic framework.

It is noteworthy that the formation of these diagnostic frameworks happens through the application of questionnaires linked to the subgroups shown in Figure 2. Such questionnaires inform the percentage of items achieved and measured through the degrees of importance and the check-list of those deliveries and formal or informal activities. This score also classifies the level that the company has reached: a standard of continuous improvement (75\% to $100 \%)$, of quality (50 to $75 \%$ ), or at the lower limit of quality of project process (up to $50 \%$ ). FAPP bottlenecks should be also perceived in degree of importance and operation in the formal deliveries of each sub-group. It is possible also to analyse separately each sub-group, its essential and differentiated deliveries or activities (AGESC, 2012; Melhado \& Oliveira, 2006), reinforcing the identification of each process difficulties.

The interface of the cited diagnostic frameworks (final reading of the tool) is represented by Figure 2:

\begin{tabular}{|c|c|c|c|c|c|c|c|c|c|c|c|}
\hline \multicolumn{5}{|c|}{ Project process } & \multicolumn{6}{|c|}{ Quality of project process } & \\
\hline DP & $\mathrm{I}$ & $\mathrm{P}$ & EMC & $\mathrm{E}$ & 11 & II & III & IV & $\mathrm{V}$ & VI & \\
\hline 13 & 16 & 12 & -9 & 4 & 19 & 9 & 11 & 15 & 16 & 26 & Activities \\
\hline$\%$ & $\%$ & $\%$ & 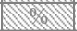 & $\%$ & N & $\%$ & $\%$ & a & $\%$ & $\%$ & $\%$ formal records \\
\hline$\%$ & $\%$ & $\%$ & $\ldots v$ & $\%$ & $\ldots$ & $\%$ & $\%$ & W. & $\%$ & $\%$ & $\%$ important and \\
\hline Ranking & Ranking & Ranking & Ranking & Ranking & Ranking & Ranking & Ranking & Ranking & Ranking & Ranking & very important \\
\hline$\%$ & $\%$ & $\%$ & $2 \%$ & $\%$ & 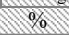 & $\%$ & $\%$ & 20 & $\%$ & $\%$ & \\
\hline G1 & G3 & G3 & C & G1 & at & G5 & G1 & a & G5 & G1 & Improvement \\
\hline G1 & G3 & G3 & Cin & G1 & 64 & G5 & G1 & dis & G5 & G1 & Weak points \\
\hline $\mathrm{G} 2$ & G3 & G3 & (c) & G1 & 10 & G5 & G1 & 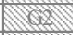 & G5 & G1 & Strengths \\
\hline 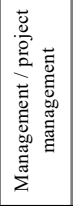 & 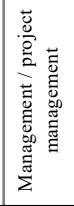 & 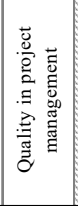 & 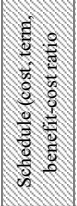 & 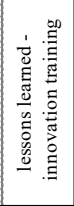 & 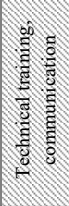 & 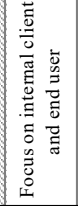 & 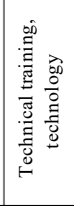 & 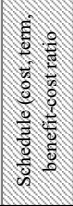 & 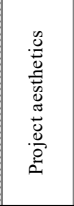 & 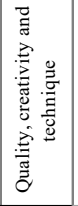 & 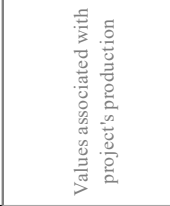 \\
\hline$\overline{D 1}$ & D2 & D3 & $\overline{\mathrm{D} 4}$ & D5 & $\mathrm{D6}$ & D7 & D8 & D9 & $\mathrm{D} 10$ & D11 & (Dn) Guidelines \\
\hline
\end{tabular}

Figure 2. FAPP diagnostic framework. Source: Adaptation of Fiuza (2015). Sub-groups: DP documents in the project plan. I - initiation. P - planning; EMC - execution, monitoring and control; $\mathrm{E}$ - closing; I - design process information flow. II - information flow - feedback. III - project team.

IV - project control. V - project presentation standards. VI - VI - Quality management.

Bottlenecks: G1 - technical training. G2 - schedule. G3 - decision-making. G4 - information flow. G5 - integration between agents. Dn: General guidelines built from the inter-relationships and inferences established in the construction of FAPP. 
The interface of the diagnostic framework represented by Figure 2 shows the bottlenecks identified for each subgroup included in the groups "design process" and "quality of the design process". It is possible to identify by means of this framework the following information: (a) a ranking of the bottlenecks that represent weak points and its location (at which step of design process this fragility is), as well as their compatible guidelines (Dn); a ranking of the points of improvement of design process, i.e. bottlenecks that can be positively influenced by strong points and do not need large investments to contribute to the quality of the process; (c) a ranking of bottlenecks that represent the strong points of design process; and, finally, (d) a ranking of bottlenecks that represent strong points of the quality of the design process. In this case, it checks the compatibility between the values associated with the project process declared by the company and the values in actual practice on the project process.

Therefore, the logic of the tool is to calculate the percentage difference of formal records in relation to the activities considered to be important and very important by the company and, in this way, obtain a ranking in function of the disparities found, listing in general the most representative bottlenecks tracked in this class of problems.

Were disregarded the columns referring to groups EMC (execution, monitoring and control), I (design process information flow) and IV (project control), compatible with the bottlenecks "schedule" and "information flow", due to this research scope, not affecting the validity of FAPP tool. Reading these bottlenecks includes their original concepts, plus technological factors explained in the expanding of this study, in the Theoretical framework.

\subsection{Functional analysis}

It is inferred from the studies of Glenn et al. (2016) that the term "meta-contingency" was used to relations between the environment (company A) and behavior (project team), operating on a global level. It was considered for this analysis: the project team performance, former stimulus that influence this performance (opportunity to sell projects and adopt technologies), and consequences for the company (profit, reputation, quality and learning).

From Redmon \& Agnew (1991) and Glenn et al. (2016) it was assumed that the metacontingency exists when: (1) the project team's performance is the object of study; (2) the consequences of team's collective performance's are identified (events that affect the team's performance and the very company's performance); (3) a functional relationship between the team's performance and the influencing factors can be identified and analysed.

However, some characteristics of meta-contingencies included the investigation of "individual contingencies", which refer to events that operate on an individual level. For example, an individual contingency includes an immediate previous stimulus (the manager who assigned a task to the team) and an immediate consequence (a compliment of the manager) around an individual response (partial delivery, or discipline associated with BIM model).

The term "organizational practices" was used for references to answers given by the team influenced by significant consequences to their success and survival, either for a specified time (temporary teams that include technicians and consultants and even other design companies) or conflict resolution on permanent teams. 


\section{Analysis and discussion of results}

This section aims to present the results obtained by means of two types of analysis associated: functional analysis and application of FAPP on company A.

\subsection{Application}

Figure 3 presents the interface of FAPP support tool applied to company A. The columns corresponding to the bottlenecks "schedule" and "information flow" (in grey) were not considered in the calculations, because these components can be evaluated independently:

\begin{tabular}{|c|c|c|c|c|c|c|c|c|c|c|c|}
\hline \multicolumn{5}{|c|}{ Project process } & \multicolumn{6}{|c|}{ Quality of project process } & \\
\hline DP & I & $\mathrm{P}$ & E M C & $\mathrm{E}$ & I & II & III & IV & V & VI & \\
\hline 13 & 16 & 12 & 9 & 4 & 9 & 9 & 11 & 15 & 16 & 26 & Activities \\
\hline $53.8 \%$ & $75.0 \%$ & $50.0 \%$ & $66.6 \%$ & $75.0 \%$ & $44.4 \%$ & $66.6 \%$ & $91.6 \%$ & $80.0 \%$ & $87.5 \%$ & $61.5 \%$ & $\%$ formal records \\
\hline $84.6 \%$ & $87.5 \%$ & $66.6 \%$ & $88.8 \%$ & $100.0 \%$ & $66.6 \%$ & $88.8 \%$ & $100.0 \%$ & $80.0 \%$ & $100.0 \%$ & $96.1 \%$ & $\%$ important and \\
\hline $1^{\circ}$ & $4^{\circ}$ & $3^{\circ}$ & $3^{\circ}$ & $2^{\circ}$ & $2^{\circ}$ & $2^{\circ}$ & $4^{\circ}$ & $5^{\circ}$ & $3^{\circ}$ & $1^{\circ}$ & very important \\
\hline $30.8 \%$ & $12.5 \%$ & $16.6 \%$ & $22.2 \%$ & $25.0 \%$ & $22.2 \%$ & $22.2 \%$ & $8.4 \%$ & $0.0 \%$ & $12.5 \%$ & $34.6 \%$ & \\
\hline & & G3 & G2 & & & & & & G5 & & Improvement \\
\hline G1 & & & & G1 & G4 & G5 & & & & G1 & Weak points \\
\hline & $\mathrm{G} 2$ & & & & & & G1 & $\mathrm{G} 2$ & & & Strengths \\
\hline 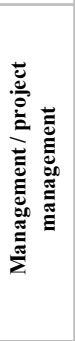 & 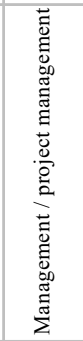 & 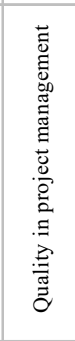 & 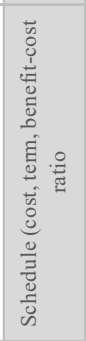 & 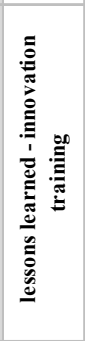 & 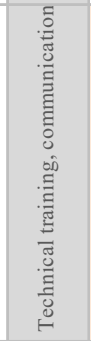 & 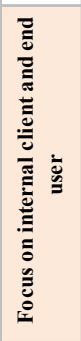 & 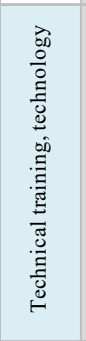 & 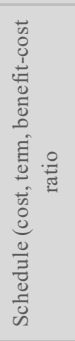 & 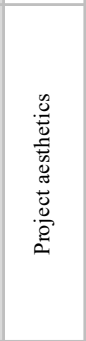 & 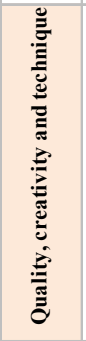 & 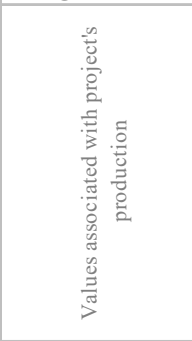 \\
\hline D1 & D2 & D3 & D4 & D5 & D6 & D7 & D8 & D9 & D10 & D11 & (Dn) Guidelines \\
\hline
\end{tabular}

Figure 3. Partial Diagnosis of company A. Source: Adaptation of Fiuza (2015).

Figure 3 summarizes the following information for the management of project process: (a) the critical subgroups in terms of disparity (they are considered important or very important, but not carried out formally). They are "DP" (documents in the project plan) in 1st place, and "E" (closing) in 2nd place, configuring the bottleneck 1. In addition, they correspond to the guidelines D1 and D5, respectively; (b) the subgroup "P" (planning) is the 3rd placed in terms of disparity and represents a segment that is balanced, but with small reflex issues; and (c) the subgroup "I" (initiation) is the 4th placed in terms of disparity, representing a segment that is balanced and does not configure fragility.

The following data is specially important for quality: (a) critical sub-groups "II" (information flow - feedback) and "Vl" (quality - management of quality) that correspond to guidelines D7 and D11, respectively; (b) projections of subgroups "III" (human resources - team) and "V" (human resources - project presentation standards) that represent the values associated with projects production, in practice.

In addition, this diagnosis presents partial incompatibility between the project associated values declared by company $\mathrm{A}$ (cost, quality and time, in that order and degree of importance) and those identified by FAPP - "technical training and technology" and "aesthetics of design", in that order and degree of importance.

Considering this result, Table 2 presents the general guidelines proposed for quality improvement of design process in company A: 
Table 2. General guidelines.

\begin{tabular}{|c|c|c|c|c|}
\hline G & $\begin{array}{l}\text { Compatible } \\
\text { values }\end{array}$ & Basic guidelines & $\begin{array}{l}\text { Suggestion for } \\
\text { actions }\end{array}$ & $\begin{array}{l}\text { Suggestion to } \\
\text { actions' focus }\end{array}$ \\
\hline G1 & $\begin{array}{l}\text { Project } \\
\text { management }\end{array}$ & $\begin{array}{l}\text { D1 - Register agents and their } \\
\text { assignments, and definition of the } \\
\text { responsibility matrix. }\end{array}$ & Project team & $\begin{array}{l}\text { Critical } \\
\text { analysis of } \\
\text { the project } \\
\text { team }\end{array}$ \\
\hline G1 & $\begin{array}{l}\text { Lessons learned } \\
\text { - innovation, } \\
\text { training. }\end{array}$ & $\begin{array}{l}\text { D5 - Data record of lessons } \\
\text { learned from project }\end{array}$ & $\begin{array}{l}\text { Administration } \\
\text { of documents }\end{array}$ & $\begin{array}{l}\text { Provide } \\
\text { project } \\
\text { guidelines, } \\
\text { R\&D }\end{array}$ \\
\hline G5 & $\begin{array}{l}\text { Focus on } \\
\text { internal client } \\
\text { and end user }\end{array}$ & $\begin{array}{l}\text { D7 - Identify the customers' needs; } \\
\text { Selection of lessons learned } \\
\text { historical data to transform them } \\
\text { into new guidelines; Feedback of } \\
\text { quality management as a whole. }\end{array}$ & $\begin{array}{l}\text { Market } \\
\text { research, } \\
\text { R\&D, project } \\
\text { process. }\end{array}$ & $\begin{array}{l}\text { Domain of } \\
\text { the product } \\
\text { generated } \\
\text { and market; } \\
\text { proposals of } \\
\text { technological } \\
\text { solutions. }\end{array}$ \\
\hline G1 & $\begin{array}{l}\text { Quality, creativity } \\
\text { and technique } \\
\text { (constructive } \\
\text { rationalization, } \\
\text { technical } \\
\text { standards, ways } \\
\text { to change). }\end{array}$ & $\begin{array}{l}\text { D11 - Systemic understanding of } \\
\text { the project process, interactions } \\
\text { and interfaces between agents, } \\
\text { activities and environments; } \\
\text { Interpretation and application of } \\
\text { Norma de Desempenho } \\
\text { [performance standards]; } \\
\text { Constructive rationalization in the } \\
\text { project. }\end{array}$ & $\begin{array}{l}\text { Quality policy } \\
\text { and the } \\
\text { relationship } \\
\text { between } \\
\text { agents and } \\
\text { the work } \\
\text { environment. }\end{array}$ & $\begin{array}{l}\text { Constant } \\
\text { concern with } \\
\text { meeting the } \\
\text { end user } \\
\text { needs. }\end{array}$ \\
\hline
\end{tabular}

Source: Adaptation of Fiuza (2015).

\subsection{Functional analysis in company $A$}

From the functional analysis in overlay to the application of FAPP it was recorded about Company A, which has structure defined for production of complex projects: it has expertise, standardizes its projects deliveries and formally registers the key activities of the documents of the project plan, which supports the steps of planning and initiation, even though there are subjectivities in the decision-making.

However, the management of different activities is, in some extent, not formalized, representing a percentage of high disparity $(36.6 \%)$ between activities that are formal and consider important or very important to the whole project process, in particular in subgroup $\mathrm{VI}$ - quality management, having a great influence on technical training in specific fields. Such activities can add value to the project and to the company because they are aimed at the needs of management, techniques and, above all, of the end user.

According to Redmon \& Agnew (1991), most of the strategies prescribed to change the individual motivation place the greatest responsibility, explicit or implied, on the manager. The highlight of the manager's leadership role in company A, present in the analysis of bottlenecks $\mathrm{G} 1$ and G3, converges to this claim, but adds the necessity of paying attention to manager's former and consequent behaviour, focusing on feedbacks transmitted by him to the team, since this individual has control over the reinforcers associated with the performance of the managed team (wages, specific training, assignment of work, access to time off, etc.), and, by consequence, over the factors that affect the final outcome of the project.

In relation to such reinforcers, at the level of individual contingency, trying a productivity factor for performance of routines, such as merit, bonus or supplementary salaries, would be interesting. Also, several compensation factors, in addition to those mentioned above, could be used as criteria to define levels of payment, as complemented 
by Muchinsky (1990), mentioning the effort, skill, responsibility and working conditions. The identification of these factors can be strategic in the reinforcements' construction.

At the level of meta-contingency, a compensation system can affect many individuals and strengthen organizational culture patterns in which they are embedded, associated with or in partnership. In this perspective, the strengthening will be enhanced if the compensation is planned aiming at the alignment of strategic objectives of projects portfolio and of the company.

Furthermore, preparation of the team in relation to use of historical data and in the process of knowledge acquisition and dissemination is a strategic action for the advancement of quality in the management of company $\mathrm{A}$. It is assumed that there is no perception that filling the more specific gaps and renewing knowledge on technological solutions is important, and it reflects, in part, in the underutilization of BIM tool. This gap weakens the decision-making and the transmission of adopted patterns, even if this is a parameter declared by the informants to evaluate projects' quality.

This statement is confirmed by the highlight of bottleneck G1 as weakness in the "closing" group, shown in Figure 2, and in the identification of absence of formal records of lessons learned, and not compatible history of technological solutions. The steps represented by the subgroups "closing", "documents in the project plan" and "quality: quality management" are potential targets for positive reinforcements, with real possibilities of being perceived, since the diagnosis of FAPP confirms that the record of lessons learned is considered very important by the project team, but it is not formally conducted.

It would be inaccurate to say that the institution of feedback systems, per se, guarantees the alignment of individual behaviour with meta-contingencies. To establish a clear link between individual performance and organization goals, it would be necessary to focus on the company capacities' management and the behaviours that are directly related with partial deliveries, something that could be visualised through a matrix of responsibilities available in compatible degrees of information for the whole team.

In terms of influence, it is expected that the end user has weight on project decisions and, in principle, independently of organizational goals. For the company it should be clear that the initial steps have the lowest cumulative impacts on project costs (PMI, 2013). As the project advances, requests for changes will increase costs and represent rework. In this case, the variables of interference and compatibilization of complementary projects can be solved by the use of BIM platform.

The representation of bottleneck G3 as a point of improvement, in Figure 2, can also be explained by the linkage between agents, assignments, and technical reports that guide choices and solutions. It is noted that the security generated by the managers of project team, with the consultants support, defers the registration of agents, the concern with feedback (by the adaptation of project's guidelines based on lessons learned) and the process of change requests.

This dynamic affects the decision-making in management of projects' portfolio, counting more on the know-how of managers than on technical reports, a weak point of quality that, in a way, negatively affects partner consultants, who feel underused, as they could act on a defined scope and collaborate with choices of rationalized technological solutions. Know-how is a critical component in the rational analysis of network shapes (Powell, 1990), related to intensive knowledge activities. In addition, it involves a kind of tacit knowledge that is difficult to codify (Nelson \& Winter, 1982; Teece et al., 1997), largely intangible and highly movable.

It is suggested that the company $A$ formalize the registration of agents and their assignments from the beginning, and take advantage of the lessons learned in order to achieve the natural points of improvement represented in Figure 2 (decision-making in the planning and integration of agents on projects presentation standards). In addition, we 
suggest adherence to integrated solutions process, initially, with complementary projects and technical procedures.

\subsection{Variables and guidelines obtained from categories of analysis}

Table 3 summarises the information obtained, assigning categories of analysis from the tracking of FAPP diagnosis; and positive aspects and weaknesses extracted by content analysis, from the functional analysis carried out. The four categories that led to this trace, according to Loss (2007), have been: critical analysis (organisational aspects), R\&D and technological solutions (technological aspects) and end user (human resources aspects). Only the category "technological solutions" did not had unfolded sub-variables.

Table 3. Variables of analysis' components.

\begin{tabular}{|c|c|c|c|c|}
\hline Diagnosis & & & unctional Analysis & \\
\hline Variables & $\mathrm{G}$ & Positive aspects & Weaknesses & Sub-variables \\
\hline \multirow{3}{*}{ Critical analysis } & \multirow{3}{*}{ G1 } & $\begin{array}{l}\text { Essential activities are } \\
\text { formal. }\end{array}$ & $\begin{array}{l}\text { Differentiated activities are } \\
\text { informal }\end{array}$ & Activities \\
\hline & & $\begin{array}{c}\text { Small and cohesive } \\
\text { team. }\end{array}$ & $\begin{array}{l}\text { With no self-evaluation of } \\
\text { the managers and the team. }\end{array}$ & Self-evaluation \\
\hline & & $\begin{array}{l}\text { Seek support in BIM } \\
\text { tool. }\end{array}$ & BIM Underutilization & BIM/collaboration \\
\hline \multirow{3}{*}{\multicolumn{2}{|c|}{ Table 3. Continued... }} & Managers' feeling. & $\begin{array}{l}\text { Fragile G3, degrades the } \\
\text { performance of } \mathrm{G} 1 \text { with this } \\
\text { focus. }\end{array}$ & Decisions \\
\hline & & $\begin{array}{l}\text { General Technical } \\
\text { training. }\end{array}$ & $\begin{array}{l}\text { Do not know how to relate } \\
\text { PP with the bank of } \\
\text { historical data. }\end{array}$ & Information \\
\hline & & Managers' feeling. & Application of resources. & Resources \\
\hline $\begin{array}{l}\text { Technological } \\
\text { solutions }\end{array}$ & G5 & Strong execution stage. & $\begin{array}{l}\text { BIM - Collaborative } \\
\text { Environment }\end{array}$ & BIM/collaboration \\
\hline \multirow{4}{*}{ End user } & \multirow{4}{*}{ G1 } & $\begin{array}{l}\text { Expertise in the market } \\
\text { in which it operates. }\end{array}$ & $\begin{array}{l}\text { Declared values of design } \\
\text { process are not compatible } \\
\text { with the values obtained in } \\
\text { the diagnosis, in order and } \\
\text { degree of importance. }\end{array}$ & Values \\
\hline & & Standardizes deliveries. & BIM Underutilization & BIM/collaboration \\
\hline & & $\begin{array}{l}\text { Training for the general } \\
\text { development of the } \\
\text { projects. }\end{array}$ & $\begin{array}{l}\text { Compatibility process is still } \\
\text { fragmented; underuse of } \\
\text { BIM. }\end{array}$ & $\begin{array}{l}\text { BIM/information } \\
\text { modelling }\end{array}$ \\
\hline & & $\begin{array}{l}\text { Initiation, planning, and } \\
\text { execution segments } \\
\text { strengthened. }\end{array}$ & $\begin{array}{c}\text { Fragile segments: } \\
\text { monitoring, control and } \\
\text { closing. }\end{array}$ & Values \\
\hline
\end{tabular}

Thus, the seven variables for the development of a technological-collaborative environment were identified: activities, self-evaluation, BIM (which unfolds into three categories of analysis), decisions, information, resources and values (which unfold into two categories of analysis). Then, the following general guidelines have been identified, by content analysis (Table 4):

Table 4. Related variables and guidelines.

\begin{tabular}{ccl}
\hline Variables & Sub-variables & Management general guidelines \\
\hline Activities & Formalize the differentiated data. \\
\hline
\end{tabular}




\begin{tabular}{|c|c|c|}
\hline Variables & Sub-variables & Management general guidelines \\
\hline \multirow{3}{*}{$\begin{array}{l}\text { Critical } \\
\text { analysis }\end{array}$} & \multirow{2}{*}{ Self-evaluation } & $\begin{array}{c}\text { Evaluate the project team's and managers' performance in } \\
\text { conflict resolution, resource allocation and individual and } \\
\text { collective physical deliveries. }\end{array}$ \\
\hline & & $\begin{array}{l}\text { Developing trust between agents. Learning is the result of } \\
\text { sharing and disseminate information, management of } \\
\text { information modelling and tacit and explicit knowledge. }\end{array}$ \\
\hline & $\begin{array}{l}\text { BIM/ } \\
\text { collaboration }\end{array}$ & $\begin{array}{l}\text { The BIM tool is a "tool" to assist in the learning process. } \\
\text { The focus must be a collaborative environment. }\end{array}$ \\
\hline \multirow{3}{*}{ R\&D } & Decisions & $\begin{array}{l}\text { Adjust design solutions from the project documentation, } \\
\text { lessons learned, and manager feeling. }\end{array}$ \\
\hline & Information & $\begin{array}{l}\text { Transform bank of historical data and lessons learned in } \\
\text { requirements to be used as feedback in the next projects. }\end{array}$ \\
\hline & Resources & $\begin{array}{l}\text { Focus and investment in technical training, technology, } \\
\text { and project's aesthetics (they are values associated with } \\
\text { PP in practice, and they have room for improvement). }\end{array}$ \\
\hline $\begin{array}{l}\text { Technological } \\
\text { solutions }\end{array}$ & $\begin{array}{l}\mathrm{BIM} / \\
\text { collaboration }\end{array}$ & $\begin{array}{l}\text { Align and link projects decisions with consultants' technical } \\
\text { advice. }\end{array}$ \\
\hline \multirow{4}{*}{ End user } & Values & $\begin{array}{l}\text { Implement and support policies and strategies to align } \\
\text { declared values and practised values. }\end{array}$ \\
\hline & $\begin{array}{c}\text { BIM/ } \\
\text { collaboration }\end{array}$ & Establish goals for the development of BIM platform. \\
\hline & $\begin{array}{l}\text { BIM / } \\
\text { information } \\
\text { modelling }\end{array}$ & $\begin{array}{l}\text { Add value to the information generated by PP coordination } \\
\text { in BIM - coordination of disciplines. }\end{array}$ \\
\hline & Values & $\begin{array}{l}\text { Focus and investment in technical training, technology, } \\
\text { and project's aesthetics (they are values associated with } \\
\text { PP in practice, and they have room for improvement). }\end{array}$ \\
\hline
\end{tabular}

\section{Final considerations}

This article has presented the foundations for the development of an analysis framework for architectural design and urban planning companies, compatible with technological-collaborative management, the BIM domain. In this way, the study of management bottlenecks was presented building what Lacerda et al. (2013) called "the vocabulary of a domain" as a support for the characterization and systematization of a class of problems originated from the lack of knowledge absorption in project companies, in the segment of $A E C$ in the Brazilian scenario.

In this sense, we highlighted the main concepts of the technological paradigm inherent to the advancement in BIM domain from three fields of knowledge - Administration, AEC, and Behavioural Analysis - aligning the configuration of collaborative networks (Jarillo, 1988; Powell, 1990; Saxton, 1997; Cândido \& Abreu, 2000; Loss, 2007), technologicalcollaborative environments (Manzione, 2013; Eastman et al., 2014), and interlacing of agents in the network (Malott, 2003; Malott \& Glenn, 2006; Glenn et al., 2016).

The main contribution of this research focuses on learning and knowledge absorption processes in project companies, seeking to highlight the gaps in technologicalcollaborative environment, and the phenomenon of cooperation and collaboration. Another important contribution was to expand the study of management bottlenecks by means of a support tool (FAPP) associated to functional analysis. Thus, it was possible to identify seven variables (activities, self-assessment, BIM, decision-making, information, 
resources and values), taking as a reference Loss (2007), representing organizational, technological and human aspects and their respective general guidelines.

However, the associations carried out during FAPP application and functional analysis does not show causal link between the analysed bottlenecks, but the correlation and interaction between variables in the perspective of Administration, AEC, and AC.

Also noteworthy is that the application of FAPP identifies fragmented practices of design process in design companies. It shows that both parallel or sequential strategy from the current productive model is fragmented, and this productive model is a reflection of a mental model that is also fragmented.

Thus, the actual progress of BIM technological innovation in socio-technical systems built in design companies, in network or not, involves convergence and interaction of technological, procedural and human factors. It assumes, mainly, the advancement on this fragmented mental model by means of a clear and systemic understanding of shared production processes, encouraging a learning environment and, particularly, improving skills in BIM.

In this context, the strengthening of non-technological aspects could be a enabling factor for the development of collaborative networks in the internal perspective of the national companies. Providing for more efficient information flow prepares them for bring about skills in partnerships, a natural trend on the segment, linking service providers, technical consultants and other companies.

Strategic networks or strategic communities are possible definitions to translate these associations - investigated as triggers for knowledge absorption and diffusion, uniting resources for a given period, in order to achieve a goal, e.g., participating in biddings with BIM project parameters (Jarillo, 1988; Tomomitsu et al., 2018).

The survey corroborates with the studies of Loss (2007) on the relevance of cooperation and interoperability agreements as influencing factors for the implementation of environments that establish cooperation, common infrastructures, trust and stimulus to sources of innovation and exploitation of opportunities, that may, for Kuehnle and Wagenhaus (2008), benefit SMEs, a important possibility, since most of Brazilian design companies are inserted in this segment.

Finally, it is recommended, for future studies, the development and implementation of an Analysis Framework based on the variables identified in studies and analyses that confirm the compatibility of the general guidelines presented and of the relationships between the variables in a representative sample. It would be interesting to corroborate or question the results obtained, in addition to achieve a structure that is relevant to project companies' actual reality.

\section{References}

American Institute of Architects - AIA. (2007). Integrated project delivery (62 p.). Sacramento: AIA California Council.

Andery, M. A. P. A. (2010). Especificidades e implicações da interpretação da linguagem como comportamento verbal. In E. Z. Tourinho \& S. V. Luna (Eds.), Análise do comportamento: investigações históricas, conceituais e aplicadas (pp. 66-99). São Paulo: Roca.

Arthur, W. B. (2010). The nature of technology: what it is and how it evolves. New York: Penguin Books.

Associação Brasileira de Normas Técnicas - ABNT. (2005). NBR ISO 9000 - Sistemas de gestão da qualidade - Fundamentos e vocabulário. Rio de Janeiro: ABNT. 
Associação Brasileira dos Gestores e Coordenadores de Projeto - AGESC. (2012). Manual de escopo de projetos e serviços de coordenação de projetos. São Paulo. Retrieved in 2016, November 15, from http://www.manuaisdeescopo.com.br/

Austin, S., Newton, A., Steele, J., \& Waskett, P. (2002). Modeling and managing project complexity. International Journal of Project Management, 20(3), 191-198. http://dx.doi.org/10.1016/S0263-7863(01)00068-0.

Baird, K., Harrison, G. \& Reeve, R. (2007). The culture of Australian organizations and its relation with strategy. International Journal of Business Studies., 15, 15-41.

Beber, M. (2008). Gerenciamento do projeto na ótica do gerenciamento da comunicação: manual para escritórios de arquitetura (Dissertação de mestrado). Universidade Federal do Paraná, Curitiba.

Beer, M., Eisenstat, R. A., \& Spector, B. (1999, november). Why change programs don't produce change. Harvard Business Review. Retrieved in 2016, December 28, from https://hbr.org/1990/11/why-change-programs-dont-produce-change

Bhattacharya, R., Devinney, T. M., \& Pillutla, M. M. (1998). A formal model of trust based on outcomes. Academy of Management Review, 23(3), 459-472. http://dx.doi.org/10.5465/amr.1998.926621.

Bleeke, J., \& Ernst, D. (1991). The way to win in cross-border alliances. Harvard Business Review, 69(6), 127-135. PMid:10114925.

Blumenschein, R. N. (2004). A sustentabilidade na cadeia produtiva na indústria da construção (Tese de doutorado). Universidade de Brasília, Brasília.

Boud, D., Cressey, P., \& Docherty, P. (Eds.). (2006). Productive reflection at work: learning for changing organizations. London: Routledge. http://dx.doi.org/10.4324/9780203001745.

Brandon, P. S. (2009). Collaboration: a technology or human interface problem? In G. Shen, P. Brandon \& A. Baldwin (Eds.), Collaborative construction information management (pp. 18-35). Oxon, UK: Spon Press

Brasil. (2006, 15 de dezembro). Lei complementar $n^{\circ} 123$, de 14 de dezembro de 2006. Institui o Estatuto Nacional da Microempresa e da Empresa de Pequeno Porte [...]. Brasília, DF: Diário Oficial da União. https://www2.camara.leg.br/legin/fed/leicom/2006/leicomplementar-123-14dezembro-2006-548099-publicacaooriginal-156405-pl.html.

Bronder, C., \& Pritzl, R. (1992). Developing strategic alliances: a conceptual framework for successful cooperation. European Management Journal, 10(4), 412-420. http://dx.doi.org/10.1016/0263-2373(92)90005-O.

Cândido, G. A., \& Abreu, A. F. (2000). Os conceitos de redes e as relações interorganizacionais: um estudo exploratório. In Anais do $24^{\circ}$ Encontro da ANPAD (EnANPAD). Maringá: ANPAD.

Charef, R., Alaka, H., \& Emmitt, S. (2018). Beyond the third dimension of BIM: A systematic review of literature and assessment of professional views. Journal of Building Engineering, 19(April), 242-257. http://dx.doi.org/10.1016/j.jobe.2018.04.028.

Eastman, C., Teicholz, P., Sacks, R., \& Liston, K. (2014). Manual de BIM. Porto Alegre: Bookman.

Fellows, R., \& Liu, A. M. M. (2013). Use and misuse of the concept of culture. Construction Management and Economics, 31(5), 401-422. http://dx.doi.org/10.1080/01446193.2013.794296.

Fenby-Taylor, H., Thompson, N., Philp, D., MacLaren, A., Rossiter, D., \& Bartley, T. (2016). Scotland global BIM study. Edinburgh: Heriot-Watt Univ.

Fiuza, P. (2015). Diagnóstico da qualidade do processo do projeto com foco na comunicação e integração entre agentes: FAPP - uma ferramenta de apoio (Dissertação de mestrado). Universidade de Brasília, Brasília.

Flick, U. (2009). Introdução à pesquisa qualitativa (3. ed.). Porto Alegre: Artmed. 
Ford, E. W., Duncan, W. J., Bedeian, A. G., Ginter, P. M., Rousculp, M. D., \& Adams, A. M. (2003). A pesquisa que faz diferença. Revista de Administração de Empresas, 43(4), 86-101. http://dx.doi.org/10.1590/S0034-75902003000400012.

Franco, L. S., \& Agopyan, V. (1994). Implementação da racionalização construtiva na fase de projeto (Boletim Técnico). Escola Politécnica, Universidade de São Paulo. São Paulo.

Franco, M. J. B. (2007). Tipologia de processos de cooperação empresarial: uma investigação empírica sobre o caso português. Revista de Administração Contemporânea, 11(3), 149-176. http://dx.doi.org/10.1590/S1415-65552007000300008.

Garcia, A., Mollaoglu, S., \& Syal, M. (2018). Implementation of BIM in small home-building businesses. Practice Periodical on Structural Design and Construction, 23(2). http://dx.doi.org/10.1061/(ASCE)SC.1943-5576.0000362.

Glenn, S. S., Malott, M. E., Andery, M. A. P. A., Benvenuti, M., Houmanfar, R. A., Sandaker, I., Todorov, J. C., Tourinho, E. A., \& Vasconcelos, L. A. (2016). Toward consistent terminology in a behaviorist approach to cultural analysis. Behavior and Social Issues, 25(1), 11-27. http://dx.doi.org/10.5210/bsi.v25i0.6634.

Godoy, C. K., Silva, A. B., \& Mello, R. B. (Eds.). (2012). Pesquisa qualitativa em estudos organizacionais: paradigmas, estratégias e métodos (2. ed). São Paulo: Saraiva.

Grupo Técnico BIM - GTBIM. (2015). Guia Asbea boas práticas em BIM (Vol. II). São Paulo: Asbea. [Manual].

Gu, N., \& London, K. (2010). Understanding and facilitating BIM adoption in the AEC industry. Automation in Construction, 19(8), 988-999. http://dx.doi.org/10.1016/j.autcon.2010.09.002.

Gusberti, T. D. H., Echeveste, M. E. S., Silva, M. H. C. M., \& Facchini, A. R. (2015). Gestão baseada em capacidades para novas empresas de base tecnológica: framework para Gestão do Processo de Conversão de Tecnologias. Gestão \& Produção, 22(4), 920-934. http://dx.doi.org/10.1590/0104-530X376-12.

Harun, A. N., Samad, S. A., Nawi, M. N. M., \& Haron, N. A. (2016). Existing practices of Building Information Modeling (BIM) implementation in the public sector. International Journal of Supply Chain Management, 5(4), 166-177. Retrieved in 2018, July 23, from http://ojs.excelingtech.co.uk/index.php/IJSCM/article/view/1372/pdf

Helfat, C. E., Finkelstein, S., Mitchell, W., Peteraf, M., Singh, H., Teece, D., \& Winter, S. G. (2007). Dynamic capabilities: understanding strategic change in organizations. Oxford: WileyBlackwell.

Hennart, J., \& Zeng, M. (2002). Cross-cultural differences and joint venture longevity. Journal of International Business Studies, 33(4), 699-716. http://dx.doi.org/10.1057/palgrave.jibs.8491040.

Holland, J. G. (2016). Os princípios comportamentais servem para os revolucionários? Revista Brasileira de Terapia Comportamental e Cognitiva, 18, 104-117. http://dx.doi.org/10.31505/rbtcc.v18i0.863.

Houmanfar, R. A., \& Mattaini, M. A. (2016). Leadership and cultural change: implications for behavior analysis. The Behavior Analyst, 39(1), 41-46. http://dx.doi.org/10.1007/s40614-0160064-7. PMid:27606189.

Indiana University (2015). Building Information Modeling (BIM) Guidelines and Standards for Architects, Engineers, and Contractors. [Manual].

Inkpen, A. C., \& Beamish, P. W. (1997). Knowledge, bargaining power, and the instability of international joint ventures. Academy of Management Review, 22(1), 177-202, from https://journals.aom.org/doi/abs/10.5465/amr.1997.9707180263. http://dx.doi.org/10.5465/amr.1997.9707180263.

Jarillo, J. C. (1988). On strategic networks. Strategic Management Journal, 9(1), 31-41. http://dx.doi.org/10.1002/smj.4250090104. 
Kodama, M. (2005). New knowledge creation through leadership-based strategic community: a case of new product development in IT and multimedia business fields. Technovation, 25(8), 895-908. http://dx.doi.org/10.1016/j.technovation.2004.02.016.

Kogut, B., \& Zander, U. (1992). Knowledge of the firm, combinative capabilities, and the replication of technology. Organization Science, 3(3), 383-397. http://dx.doi.org/10.1287/orsc.3.3.383.

Kolarevic, B. (2005). Architecture in the digital age: design and manufacturing (1st ed.). Oxford: Taylor \& Francis Group.

Kuehnle, H., \& Wagenhaus, G. (2008). Monitoring and Control of Collaborative Innovation in Small Firms' networks. In 2008 IEEE International Technology Management Conference (ICE). Piscataway: IEEE.

Lacerda, D. P., Dresch, A., Proença, A., \& Antunes Júnior, J. A. V. (2013). Design Science Research: método de pesquisa para a engenharia de produção. Gestão \& Produção, 20(4), 741-761. http://dx.doi.org/10.1590/S0104-530X2013005000014.

Loss, L. (2007). Um arcabouço para o aprendizado de redes colaborativas de organizações: uma abordagem baseada em aprendizagem organizacional e gestão do conhecimento (Tese de doutorado). Universidade Federal de Santa Catarina, Florianópolis.

Malott, M. E. (2003, May). Paradox of organizational change: engineering organizations with behavioral systems analysis. Reno, NV: Context Press.

Malott, M. E., \& Glenn, S. S. (2006). Targets of intervention in cultural and behavioral change. Behavior and Social Issues, 15(1), 31-56. http://dx.doi.org/10.5210/bsi.v15i1.344.

Manzione, L. (2013). Proposição de uma estrutura conceitual de gestão do processo colaborativo com o uso do BIM (Tese de doutorado). Escola Politécnica, Universidade de São Paulo, São Paulo.

March, S. T., \& Smith, G. F. (1995). Design and natural science research in Information Technology. Decision Support Systems, 15(4), 251-266. http://dx.doi.org/10.1016/01679236(94)00041-2.

Melhado, S. B. (1994). Qualidade do projeto na construção de edifícios: aplicação ao caso das empresas de incorporação e construção (Tese de doutorado). Escola Politécnica, Universidade de São Paulo, São Paulo.

Melhado, S. B., \& Oliveira, O. J. (2006). Como administrar empresas de projeto de arquitetura e engenharia civil. São Paulo: Pini.

Muchinsky, P. M. (1990). Psychology applied to work. Pacific Grove, CA: Brooks-Cole.

National Building Specification - NBS. (2017). National BIM report. Newcastle, UK: NBS.

Nelson, R. R., \& Winter, S. G. (1982). An evolutionary theory of economic change. Cambridge: The Belknap Press of Harvard University Press.

Oliveira, D. P. R. (2013). Administração de projetos: melhores práticas para otimizar resultados. São Paulo: Atlas.

Oliver, A. L., \& Ebers, M. (1998). Networking network studies: an analysis of conceptual configurations in the study of inter-organizational relationships. Organization Studies, 19(4), 549-583. http://dx.doi.org/10.1177/017084069801900402.

Osland, G. E., \& Cavusgil, S. T. (1996). Performance issues in U.S. - China joint ventures. California Management Review, 38(2), 106-130. http://dx.doi.org/10.2307/41165835.

Owen, R., Amor, R., Palmer, M., Dickinson, J., Tatum, C. B., Kazi, A. S., Prins, M., Kiviniemi, A., \& East, B. (2010). Challenges for integrated design and delivery solutions. Architectural Engineering and Desing Management, 6(4), 232-240. http://dx.doi.org/10.3763/aedm.2010.IDDS1.

Parkhe, A. (1991). Interfirm diversity, organizational learning, and longevity in global strategic alliances. Journal of International Business Studies, 22(4), 579-601. http://dx.doi.org/10.1057/palgrave.jibs.8490315. 
Parolia, N., Goodman, S., Li, Y., \& Jiang, J. (2007). Mediators between coordination and IS project management. Information \& Management, 44(7), 635-645. http://dx.doi.org/10.1016/j.im.2007.06.003.

Penn State BIM. (2012). Project Execution Planning Guide and Templates - Version 2.0 BIM Project Execution Planning, CIC Research Group, Department of Architectural Engineering, The Pennsylvania State University. [Manual].

Ping Tserng, H., \& Lin, Y. C. (2004). Developing an activity-based knowledge management system for contractors. Automation in Construction, 13(6), 781-802. http://dx.doi.org/10.1016/j.autcon.2004.05.003.

Powell, W. W. (1990). Neither market nor hierarchy: networks forms of organization. Research in Organizational Behavior, 12, 295-336. Retrieved in 2017, January 12, from http://www.uvm.edu/pdodds/files/papers/others/1990/powell1990a.pdf

Prins, M., \& Owen, R. (2010). Integrated design and delivery solutions. Architectural Engineering and Design Management, 6(4), 227-231. http://dx.doi.org/10.3763/aedm.2010.IDDS0.

Project Management Institute - PMI. (2013). A guide to the project management body of knowledge (5. ed.). São Paulo: Saraiva.

Redmon, W. K., \& Agnew, J. A. (1991). Organizational behavioral analysis in United States: a view from the private sector. In P. A. Lamal (Ed.), Behavioral analysis of societies and cultural practices (pp. 125-139). North Carolina: University of North Carolina.

Savory, C. (2006). Translating knowledge to build technological competence. Management Decision, 44(8), 1052-1075. http://dx.doi.org/10.1108/00251740610690612.

Saxton, T. (1997). The effects of partner and relationship characteristics on aliance outcomes. Academy of Management Journal, 40(2), 443-461. http://dx.doi.org/10.2307/256890.

Schon, D. (1984). The reflective practitioner: how professionals think in action (1st ed.). New York: Basic Books.

Simon, H. A. (1996). The sciences of the artificial (3rd ed.). Cambridge: MIT Press.

Simon, H. A. (1997). Administrative behavior: a study of decision-making processes in administrative organizations. London: The Free Press.

Skinner, B. F. (1957). O comportamento verbal (1. ed.). São Paulo: Cultrix.

Teece, D. J., Pisano, G., \& Shuen, E. (1997). Dynamic capabilities and strategic management. Strategic Management Journal, 18(1), 509-533. http://dx.doi.org/10.1002/(SICI)10970266(199708)18:7<509::AID-SMJ882>3.0.CO;2-Z.

Tomomitsu, H. T. A., Carvalho, M. M., \& Moraes, R. O. (2018). A evolução da relação entre a gestão de projetos e a gestão do conhecimento: um estudo bibliométrico. Gestão \& Produção, 25(2), 354-369.

Triviños, A. N. S. (1987). Introdução à pesquisa em ciências sociais: a pesquisa qualitativa em educação. São Paulo: Atlas.

US Army Corps of Engineer - USACE. (2012). The US Army Corps of Engineers Roadmap for LifeCycle Building Information Modeling (BIM). Supplement 1 - BIM Implementation Guide for Military Construction (MILCON) Projects Using the Autodesk Platform. USA: Autodesk, Inc. [Manual]

Van Aken, J. E. (2004). Management research based on the paradigm of the design sciences: the quest for field - tested and grounded technological rules. Journal of Management Studies, 41(2), 219-246. http://dx.doi.org/10.1111/j.1467-6486.2004.00430.x.

Viotti, E. B. (1997). Passive and active national learning systems: a framework to understand technical change in late industrializing economies and some evidences from a comparative study of Brazil and South Korea (Ph.D. dissertation). The New School University, New York.

Wheelwright, S. C., \& Clark, K. B. (2011). Revolutionizing product development quantum leaps in speed, efficiency, and quality. New York: Free Press. 
Wong, A. K. D., Wong, F. K. W., \& Nadeem, A. (2010). Attributes of building information modelling implementations in various countries. Architectural Engineering and Design Management, 6(4), 288-302. http://dx.doi.org/10.3763/aedm.2010.IDDS6.

Wu, W., Mayo, G., McCuen, T. L., Issa, R. R. A., \& Smith, D. K. (2018). Construction parts in building projects: definition and case study. Journal of Management Engineering, 34(4). http://dx.doi.org/10.1061/(ASCE)ME.1943-5479.0000616.

Yarmohammadi, S., \& Castro-Lacouture, D. (2018). Automated performance measurement for 3D building modeling decisions. Automation in Construction, 93, 91-111. http://dx.doi.org/10.1016/j.autcon.2018.05.011.

Yin, R. K. (2001). Estudo de caso: planejamento e métodos. Porto Alegre: Bookman. 